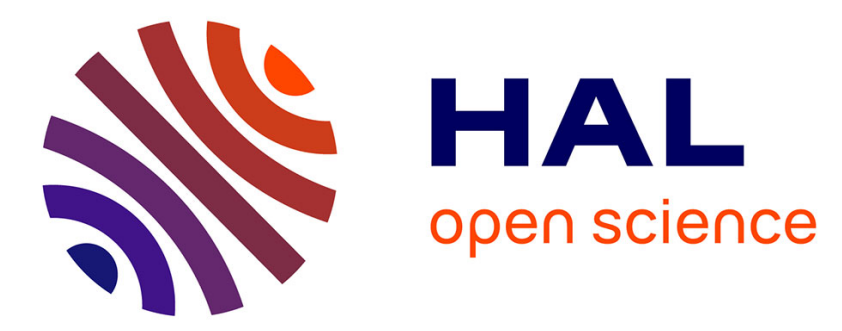

\title{
Great Bustard () nest locations in relation to leks
}

Marina Magaña, Juan C. Alonso, Javier A. Alonso, Carlos A. Martín, Beatriz

Martín, Carlos Palacín

\section{To cite this version:}

Marina Magaña, Juan C. Alonso, Javier A. Alonso, Carlos A. Martín, Beatriz Martín, et al.. Great Bustard () nest locations in relation to leks. Journal für Ornithologie $=$ Journal of Ornithology, 2010, 152 (3), pp.541-548. 10.1007/s10336-010-0625-6 . hal-00646465

\section{HAL Id: hal-00646465 https://hal.science/hal-00646465}

Submitted on 30 Nov 2011

HAL is a multi-disciplinary open access archive for the deposit and dissemination of scientific research documents, whether they are published or not. The documents may come from teaching and research institutions in France or abroad, or from public or private research centers.
L'archive ouverte pluridisciplinaire HAL, est destinée au dépôt et à la diffusion de documents scientifiques de niveau recherche, publiés ou non, émanant des établissements d'enseignement et de recherche français ou étrangers, des laboratoires publics ou privés. 


\title{
Great Bustard (Otis tarda) nest locations in relation to leks
}

\author{
Marina Magaña ${ }^{1}$, Juan C. Alonso ${ }^{1}$, Javier A. Alonso², Carlos A. Martín ${ }^{1}$, Beatriz \\ Martín ${ }^{1}$, Carlos Palacín ${ }^{1}$
}

${ }^{1}$ Departamento de Ecología Evolutiva, Museo Nacional de Ciencias Naturales, CSIC, José

Gutiérrez Abascal 2, E-28006; Madrid, Spain

${ }^{2}$ Departamento de Biología Animal, Facultad de Biología, Universidad Complutense, E-28040

Madrid, Spain

*Corresponding author

e-mail: marinam@mncn.csic.es 


\begin{abstract}
We investigated the spatial arrangement of Great Bustard nests relative to leks in 55 females captured at four lek sites and radio-tracked through 1-6 years in a protected area in central Spain. Although females showed a tendency to nest close to the lek centres where they were observed during the mating season $(29 \%$ did it at $<2 \mathrm{~km})$, lek-to-nest distances ranged between $0.22-53.82 \mathrm{~km}$. This resulted in most nest-sites (64\%) being outside the lek areas where the female had mated, often closer to nearby leks, and sometimes far from any lek, in areas used only for nesting, outside the protected area (25\%). The distribution of nest-to-nearest-lek distances did not differ from that of randomly distributed control sites, indicating that nest-sites were not aggregated, but dispersed over the whole suitable habitat within a large area around leks. Females with and without hatching success did not differ in their mean lek-to-nest distance. These results suggest that females used the whole suitable habitat available for nesting, and did not base nest-site selection on factors related to density-dependent disturbances or predation risks at leks (lek avoidance hypothesis). In this and other lekking birds, managers have often restricted conservation efforts to lek areas, under the wrong assumption that these would include most nest-sites. If a much larger region including most nesting habitat is not protected, great bustards in our study population might eventually be forced to nest at higher densities within the protected area, with a consequent density-dependent reduction in the mean breeding success of the population.
\end{abstract}

Keywords Great bustard - Lek - Nest-site - Conservation - Habitat management 


\section{Zusammenfassung}

\section{Nestwahl und Balzplätze bei der Großtrappe (Otis tarda)}

Für 55 Großtrappen-Weibchen, die an 4 Balzplätzen gefangen und mittels kleiner Sender über 1-6 Jahre in einem Naturschutzgebiet in Zentralspanien verfolgt wurden, untersuchten wir die räumliche Verteilung der Nester in Beziehung zu den Balzplätzen. Zwar zeigten die Weibchen eine Tendenz, nahe desjenigen Balzplatzes zu nisten, an dem sie während der Balzzeit beobachtet worden waren (weniger als $2 \mathrm{~km}$ entfernt bei $29 \%$ der Tiere), aber die Entfernungen der Nester von den Balzplätzen reichten von 0,22 bis 53,82 km. 64\% aller Nistplätze lagen außerhalb der Balzplatz-Areale, in denen die Weibchen begattet worden waren, manchmal näher zu anderen Balzplätzen und gelegentlich (in 25\% der Fälle) weit entfernt von irgendwelchen Balzplätzen, außerhalb des Naturschutzgebietes, und nur zum Nisten ausgewählt. Die Verteilung der Entfernungen „Nest zum nächstgelegenen Balzplatz“ unterschied sich nicht signifikant von derjenigen der zufällig ausgesuchten Kontroll-Areale, was den Schluss nahe legt, dass die Nester nicht irgendwo gehäuft auftraten, sondern sich über das gesamte geeignete Habitat innerhalb eines weiten Gebietes um die Balzplätze herum verteilten. Auch zwischen Weibchen mit und ohne Bruterfolg konnte kein Unterschied in den Entfernungen ihrer Nester von den Balzplätzen festgestellt werden. Diese Ergebnisse lassen vermuten, dass die Weibchen bei der Wahl des Nistplatzes das gesamte, zum Nisten geeignete Habitat nutzten, ohne Berücksichtigung von Faktoren wie Nistplatzdichte oder spezielles Beute-Risiko (Balzplatz-Vermeidungs-Hypothese). Bei dieser und anderen Arten mit vergleichbarem Balzverhalten wurden Schutzmaßnahmen oft auf die Balzplätze begrenzt, in der irrigen Annahme, diese enthielten die meisten Nistplätze. Aber wenn nicht ein größeres Gebiet, inklusive der meisten Nistplätze, geschützt wird, könnten die Großtrappen der von uns untersuchten Population einmal gezwungen sein, innerhalb des geschützten Gebiets in größerer Dichte zu nisten, mit dem im Mittel durch die Dichte verursachten geringeren Bruterfolg der Population. 


\section{Introduction}

The Great Bustard Otis tarda is a steppe bird inhabiting open grassland areas of the Palaearctic region (del Hoyo et al. 1996). Today the species is considered globally threatened, after having suffered declines during the 20th century, due mostly to hunting, agricultural intensification and human-induced habitat fragmentation (Heredia et al. 1996; BirdLife International 2004). Population viability analyses have revealed that nest losses and juvenile mortality are crucial parameters affecting the survival probabilities of small populations (Streich et al. 1996; Lane and Alonso 2001; Martín 2008). Field studies have shown that nest losses and chick mortality are high in this species, and may largely be attributable to destruction by agricultural machinery, predation, and starvation (Ena et al. 1987; Magaña 2007; Martín et al. 2007). Recently, predator control and habitat improvement measures have contributed to the stabilization of endangered great bustard populations, presumably through increasing productivity. It seems therefore that management of the nesting habitat may be one of the most effective measures to improve the conservation status of this species (Farago et al. 2001; Langgemach and Bellebaum 2005; own unpubl. data). The need to protect nesting areas has been acknowledged both, in the species European Action Plan (Kollar 1996) and in the Spanish inventory of Important Bird Areas (Viada 1998). However, because recognizing suitable nesting areas based on habitat cues is difficult, in this and other lekking species managers have generally used leks to identify nesting habitats, and consequently restricted conservation efforts to such lek areas. This restriction has been so for practical reasons, i.e. to optimize the limited resources available for conservation, but also based on the assumption that most nests are usually found within or close to lek areas (see e.g., Wegge and Rolstad 1986; Johnsgard 1994; Höglund and Alatalo 1995; Connelly et al. 2000). However the spatial distribution of nests relative to lek site is still 
debated. While in some species females nest close to the lek where they mated, which is thus interpreted as an important center of nesting activity (Pepper 1972; Conelly et al. 2000; Bradbury et al. 1989), in others nests are aggregated around the periphery of leks possibly because habitat between lekking males is unsuitable for laying and brooding (Hingrat et al. 2008), or to minimize disturbances by strutting males and predation associated with leks (lek avoidance hypothesis, Bergerud 1988; Trail and Adams 1989). Among bustard species, the patterns of nesting dispersion remain virtually unknown (del Hoyo et al. 1996). Specifically for great bustards, some authors have reported that females nest within the lek where they mate or close to its limits, based on population surveys without marked birds (Hidalgo and Carranza 1990 in western Spain; Demeter 1995 in Hungary, Morgado and Moreira 2000 in Portugal; but see reported distances of up to $18 \mathrm{~km}$ in Glutz et al. 1973 for Germany). In the Iberian Peninsula, great bustards leks may vary in size between ca. 15-20 birds and more than 400 birds, and occupy a surface of 5-15 km² during the peak mating period in April (Magaña 2007, own unpubl. data). A recent study with a small sample of radio-tagged females reported nest-to-lek centre distances of 2-7 km in northern Spain (Alonso et al. 2000).

In this study we investigate the spatial arrangement of great bustard nests relative to leks in a large sample of females radio-tracked through several years in a protected area in central Spain. Our objectives were (a) to compare nest and lek distributions and test two predictions from the lek avoidance hypothesis: (i) nesting females would avoid lek centres, and (ii) nesting success should be higher at greater distances from the lek; (b) to test one prediction from optimal dispersion patterns (Andersson and Wiklund 1978; Bergerud and Gratson 1988), namely that (i) average lek-to-nest distance would be positively correlated with lek size; (c) to evaluate to what extent the limits of the protected area (see below, under Study area) would include most 
nest-sites; and (d) to examine whether current protection status improved nesting success with respect to nests found outside the protected area.

\section{Methods}

Study area

The study was conducted in the Important Bird Area 074 'Talamanca-Camarma' and its surrounding suitable bustard habitat $\left(40^{\circ} 40^{\prime} \mathrm{N} 3^{\circ} 25^{\prime} \mathrm{W}\right.$, between Madrid and Guadalajara provinces in central Spain), where two Special Protection Areas for birds were designated, SPA 139 ‘Estepas cerealistas de los ríos Jarama y Henares’ in 1993 and SPA 167 'Estepas cerealistas de la Campiña' in 1998 (Fig. 1). The total surface of these two protected areas is $362 \mathrm{~km}^{2}$. Through the study period, the breeding population was estimated to be ca. 1100 great bustards, distributed among 10 leks (Alonso et al. 2003, 2005). Great bustard habitat was limited westwards by a paved road and the river Jarama. Madrid capital city is located ca. $40 \mathrm{~km}$ to southwest, and between the city and the study area the landscape is mostly urbanized, or occupied by habitat not suitable for the species. The proximate great bustard areas southwards are separated by ca. $20 \mathrm{~km}$ from our study area. East- and north-eastwards there is no other known lek nearby, but the habitat is essentially appropriate, with interspersed unsuitable patches (own unpubl data; see also Osborne et al. 2001; Suárez-Seoane et al, 2002).

The terrain is flat to slightly undulating, with a mean elevation of $740 \pm 83 \mathrm{~m}$. Land use in the study area was primarily dedicated to cereal cultivation (mainly wheat Triticum aestivum and barley Hordeum spp), with minor fields of legumes (Vicia spp.) 
and a few olive groves (Olea europaea). Most cereal is grown in a traditional two-year rotation system (Suárez et al. 1997) that creates a dynamic mosaic of ploughed, cereal and stubble patches over the region (see details in Lane et al. 2001, Alonso et al. 2003). Cereal fields are harvested during late June to early July. Stubbles and fallows are also used for sheep grazing.

Field techniques

We captured 55 females at four leks $(23,5,17$ and 10 females, respectively in leks A-D, Fig.1), and marked them with PVC wing-tags and attached backpack radio-transmitters (TW3 2×AA units, 60 g, Biotrack Ltd., UK), using elastic band as harness. We radiotracked them from 1998 to 2005 using telemetry receivers (TR2-TS1, Telonics Inc., USA). Five of them were captured by chasing them down when they were 3-10 weeks old and still dependent on their mothers, and fifty using rocket nets when they were fully grown. All birds were located by triangulation (Millspaugh and Marzluff 2001) and by subsequent visual observation with a $20-60 \times$ telescope at least once per month throughout their lives. When birds moved outside of the ground tracking study area, we used E-24 Beechcraft aeroplanes from the Spanish Air Forces to locate them from the air. From the earliest matings to the latest nestings (late March-late June, Magaña 2007) we increased the tracking frequency and monitored all radio-tagged individuals on average once every 6 days (range $=2-9, \mathrm{SD}= \pm 2$ ). Locations were recorded in UTM coordinates using a GPS (Garmin 12; Garmin International, USA) and plotted on 1:50000 maps.

During nesting, we generally did not establish visual contact with females to avoid flushing them from the nest and minimize the chance of human-induced nest 
predation or nest abandonment. Instead, the position of the birds was estimated using triangulation of two or more bearings (Millspaugh and Marzluff 2001) taken from the edges of the field where the female was found, and approaching at least once to within approximately $50 \mathrm{~m}$ of the bird. Based on 10 nests for which we knew exact locations, we estimate our error in locating a nest-site was not more than ca. 5-10 m. When a female was located in the same place over two or more consecutive weeks we assumed it was nesting and considered the average of those locations as its nest-site. Four consecutive weekly locations in the same place were interpreted as a successful nesting attempt (eggs hatched, or positive hatching success), and two or three locations as unsuccessful (not hatched, or no hatching success), as incubation may last up to 28 days (Glutz et al. 1973). Nest fate could be determined for 122 nesting attempts in total, 55 of which were first-year clutches. Once the estimated incubation period was over, all hens were monitored to confirm whether they were accompanied by chicks or not, and to detect re-nesting attempts.

We conducted annual censuses of great bustard populations on the study area. Three teams of two observers simultaneously surveyed the study area using four-wheel drive vehicles, binoculars and telescopes 20-60×, GPS and maps 1:10000. Radios were used to communicate between teams to reduce the potential for double counting of individuals. Surveys started at dawn and ended at dusk, with a pause during midday (12:00-14:00 h GMT), when bustards loaf and become difficult to detect. The census itinerary was covered at low speed, with frequent stops at vantage points as they were convenient to carefully look for birds (Alonso et al. 2003). In addition, weekly surveys of each lek area were conducted from appropriate vantage points between late March and late April. 
Although classical leks are defined as clumped display areas of males that females attend primarily for the purpose of mating (e.g. Höglund \& Alatalo 1995), great bustard form exploded leks (Höglund and Alatalo 1995, Johnsgard 1994), where males display at a mean distance of $265 \mathrm{~m}$ from one another (Magaña 2007, Alonso et al. 2010). Lek areas were defined with ArcGIS 9.2 (ESRI 2005) as the minimum convex polygons encompassing all locations of males and females during the mating season (late March-late April). Our definition of lek area was appropriate for the purposes of testing the lek avoidance hypothesis, since it included all locations of males and females during the mating period in the exploded lek (details in Magaña 2007, Alonso et al. 2010), when intense display of solitary males, and mating and aggressive interactions could be thought to cause nesting females to avoid lek centres. For each lek we defined a lek centre as the average location of the male flock at display time, prior to lek explosion (1st March-15thApril). Lek-to-nest distance was the distance between the nest location of a marked female and the centre of the lek where she was seen during the mating period (late March-early May). We cannot be sure that they mated at these leks, because we only saw 4 of the 55 females actually copulating. However, only one of the 55 females was spotted at a second lek during the mating period,. Nest-to-nearest-lek distance was the distance between the nest location and the centre of the nearest lek, including all ten leks in the study area.

Statistical analyses

During the eight years of study, we located 122 nests of the 55 marked females (12 females with single year locations, 43 with multiple year locations: 27 of these on two, 11 on three, 3 on four, 1 on five and 1 on six consecutive years). The average distance 
between nests of the same female in consecutive years was $0.76 \mathrm{~km}(\mathrm{SD}= \pm 0.45, \mathrm{n}=$ 39). To avoid pseudoreplication, all analyses were carried out using only nest-sites of the first tracking year in females with multiple year nest locations, and excluding the few replacement clutches $(n=4)$ found. In the case of hatching success, analyses were repeated using all-year nests, to confirm results obtained with first-year nests. Previous studies showed that females tend to remain faithful through their lives to the leks where they mate (Magaña 2007), and also to their nesting areas (Magaña et al. 2010; a marked nest-site fidelity has also been found in other study areas, Alonso et al. 2000). To test whether females were attracted by leks when selecting nest-sites or they avoided lek centres, we first examined the frequency distribution of lek-to-nest distances. If the hypothesis that the lek is an important centre for nesting activity is correct, then a rightskewed distribution would be expected. Second, we used a modified Monte Carlo simulation (Manly 1997) to compare the distribution of nest-to-nearest-lek distances with a sample of 55 control points randomly distributed across the habitat suitable to great bustards within the study area. Random control points were generated, and distances from these points to the closest lek were calculated using Hawths Tools of ArcGIS 9.2. This was repeated 1000 times to obtain 1000 distributions of 55 distances each, and the p-value was calculated for a two-tailed distribution and a significance of 0.05. A significant difference between both distributions would mean that nests are aggregated, and the sign of the difference would indicate whether nest aggregation was around leks. We considered as suitable habitat the area used by the birds during part of, or the whole year, as obtained from 29 complete censuses of the study area performed between 1995 and 2003 (seven in spring, 22 in other seasons). Areas with no bustard sightings in patches $\geq 2 \times 2 \mathrm{~km}$ were considered non-suitable habitat (Fig. 1). The four leks for which we had data from $\geq 5$ nesting females differed in their size (numbers of 
males and females). To explore the influence of lek size on nest dispersion we analyzed the variation in mean lek-to-nest distance among the four leks through one-way ANOVA. We used two-sample Student's $t$-tests to compare mean log-transformed lekto-nest distances between successful and unsuccessful nests. We used Chi-square test to compare hatching success (i.e. the percentage of nests where at least one egg hatched) between within and outside leks, and between within and outside the SPAs. Data were analysed using STATISTICA version 6.0 (StatSoft 2001).

\section{Results}

Nesting females dispersed over a wide area around the leks where they spent the mating period (Fig. 1). The unsuitable habitat along the west margin of the study area explains the absence of nests there, and the observed selection of nesting sites towards northeast. The minimum convex polygon comprising all nests of the 55 tracked females was 16 times larger (59596 ha) than the sum of the four lek areas where they had spent the mating period (3810 ha). The mean lek-to-nest distance was $7.73 \mathrm{~km}$ (range 0.22-53.82 $\mathrm{km}, \mathrm{SD}=9.49, \mathrm{n}=55$ birds). The distribution of lek-to-nest distances was skewed, with $29 \%$ of females nesting at $<2 \mathrm{~km}$, and $55 \%$ at $<5 \mathrm{~km}$ of the centres of the leks where females had spent the mating period (Fig. 2). However, many females (64\%) nested outside their lek areas, and $25 \%$ did nest outside the SPAs and far from any lek, in areas used only for nesting (e.g., north and northeast of the SPAs, Fig. 1). The distribution of nest-to-nearest-lek distances $($ mean $=4.82, \mathrm{SD}=4.74, \mathrm{n}=55)$ did not differ from that of control sites across the suitable habitat $($ mean $=4.62$, CI 95\% $=3.01-6.43 \mathrm{~km}, 1000$ 
iterations of 55 random points, $\mathrm{p}=0.698$ ). There was no significant variation in the mean lek-to-nest distance among the four leks studied $\left(\mathrm{F}_{3,47}=1.25, \mathrm{p}=0.303\right.$, Table 1$)$.

Females with and without hatching success did not differ in their mean lek-tonest distance $(\mathrm{t}=0.53, \mathrm{p}=0.601, \mathrm{n}=53$ first-year clutches; $\mathrm{t}=1.25, \mathrm{p}=0.214, \mathrm{n}=116$ including multiple year clutches; in four cases the lek was unknown and in two cases the hatching success was unknown), nor in the nest-to-nearest-lek distance $(\mathrm{t}=0.79, \mathrm{p}=$ $0.434, \mathrm{n}=53$ first-year clutches; $\mathrm{t}=1.00, \mathrm{p}=0.321, \mathrm{n}=120$ including multiple year clutches). Hatching success did not differ between nests located within and outside the lek areas, or between nests located within and outside the Special Protection Area (Table 2).

\section{Discussion}

Nesting females dispersed over a much wider territory than the lek area occupied by males and females during the mating season. This pattern was similar in all four leks for which we had a sufficient sample of marked birds. Although for each lek the frequency distribution of lek-to-nest distances was clearly skewed, with females showing a preference to nest close to the centre of the lek where she spent the mating period, overall the majority of nests were located outside lek areas, with nesting females dispersing up to $53 \mathrm{~km}$ from their lek centres. Because lek-to-nest dispersion occurred in all directions where suitable habitat was available, and nesting dispersions from neighbour leks overlapped widely, the pattern described above resulted in an overall nest distribution which did not significantly differ from a random distribution of potential nesting sites (even considering that our sample of females was from only four 
of ten leks found in the study area). In other words, nests were found over the whole suitable habitat in the study area (shaded areas in Fig. 1), showing no clear aggregation pattern. Moreover, nesting success did not differ between females nesting close to the lek centres and far from them. These results, together with the absence of a higher nesting success at farther distances from lek centres, failed to support the two predictions derived from the lek avoidance hypothesis. Great bustards do not seem to select nest sites based on distances from leks. Nest distribution depends on other components related to topography, land-cover, farmland structure, and human features (Magaña et al. 2010). Because some of the main habitat features selected by nesting females, e.g. use of cereal and fallow fields, or avoidance of human infrastructures, coincide with the general habitat preferences of the species (Alonso and Alonso 1990; Martínez 1991a, b; Lane et al. 2001), at the scale of the whole study area the habitat suitable for nesting roughly coincides with the habitat used by the birds through the annual cycle.

As for the prediction that average lek-to-nest distance would increase for larger leks, we did not find significant differences among leks, probably due to the small number of leks used. However, the trend was suggestive of an actual influence of lek size on lek-to-nest dispersion, with the largest lek showing the greatest average nest dispersion, and the smallest lek the shortest nest dispersion (see Table 1). It is reasonable to assume that if females disperse from their leks to nest up to some tens of kilometres and occupy all available sites, the dispersion distances and areas occupied by nesting females from larger leks should be greater than those from smaller leks.

An area that attracted a particularly large number of females from at least three different leks extended 8-20 km northeast of lek A. With the exception of few sporadic observations of only some females at other times of the year, this area is occupied by 
great bustards only during the nesting season. A considerable number of females move to this area after mating to nest, but return to their leks as soon as they fail in their nesting attempt, or once their chicks have fledged, i.e., in September (pers. obs.). The existence of this nesting aggregation might be explained by a lack of sufficient nesting habitat closer to the lek areas in Madrid region (see above). An alternative and perhaps more plausible explanation might be the likely presence of a lek in this area some decades ago. It is possible that males of that lek would have gone extinct before we conducted the first surveys in this area, due to selective male trophy harvesting before the hunting ban in 1980. Alternatively, males might have disappeared from such areas because they suffer higher mortality than females, and are more sensitive to other human-induced extinction causes (Alonso et al. 2003; Martín et al. 2007; Martín 2008). A similar but smaller area used almost exclusively by nesting females near the southwest corner of the study area, ca. $6 \mathrm{~km}$ west of lek D centre, was destroyed by urban development in 2003 (area with nests 1D and 23D in Fig. 1).

The results presented here refute the conclusions of earlier studies based on population surveys with no marked birds which suggested that most great bustard females usually nested within or close to the perimeter of their leks (Hidalgo and Carranza 1990; Demeter 1995; Morgado and Moreira 2000), and extend the limits of nesting female dispersion far beyond the $2-7 \mathrm{~km}$ reported for a small sample of marked females in Alonso et al. (2000). Studies with other lekking species have also shown that a variable number of females tend to place their nests outside their lek areas (Wegge and Rolstad 1986; Schroeder and White 1993; Wakkinen et al. 1992; Holloran and Anderson 2005; Hingrat et al. 2008), and even may often nest closer to leks different from the lek where they spent the mating period (Wegge 1985; Höglund and Robertson 1990; Wakkinen et al. 1992). Although a wide dispersion of nesting females is typical 
of most lekking species (Höglund and Alatalo 1995), the factors determining the nest distribution are not clear. The distance at which galliform females nest relative to the lek where they mate varies inter- and intraspecifically from a few hundred to thousands of meters (Pepper 1972; Bradbury et al. 1989; Holloran and Anderson 2005; Hingrat et al. 2008; this study). Overall, previous research and our study suggest that females of most lekking birds tend to nest close to the leks where they spend the mating period, but many of them nest at far distances, closer to other leks, perhaps looking for free space to nest. The prevalence of nest-site and lek-site fidelity among these species, and in the case of great bustards, also the significantly shorter natal dispersal distances in females as compared to males (Alonso et al. 1998; Martín et al. 2008), supports the idea that the nesting dispersion pattern represents an evolutionary stable strategy that is more dependent on optimal dispersion and cultural transmission of nesting areas from mothers to daughters, rather than on factors related to density-dependent disturbances or predation risks at leks (lek avoidance hypothesis).

As for the conservation implications, our study shows that protecting our defined lek areas, i.e., where birds are present during the mating period, would be the most important step, since this would include ca. $50 \%$ of nests. However, focussing management efforts only within these areas would not guarantee conservation of all nesting habitats. Our data show that a buffer of ca. $8 \mathrm{~km}$ around current lek centres would include $80 \%$ of nests, and likely a much larger area of nesting habitat. Moreover, the proportion of females nesting outside the limits of the SPAs is relatively high (25\%) and could be important for population viability since their hatching success is not different to that of females nesting within the SPAs. Some of these external nesting areas are at present far away from nearest leks, possibly because male groups of leks existing there in past decades went extinct. Managers should take urgent measures to 
ensure protection of these peripheral nesting areas, and perhaps try to restore conditions appropriate for an eventual re-establishment of breeding males at them. The current boundaries of the SPAs should be extended as soon as possible to include these areas. If the whole territory identified as nesting area is not protected, the species will continue suffering the negative consequences of the conspecific aggregation process that has been operating through the last decades and has determined the current very high breeding densities at some areas (Alonso et al. 2004). Recent habitat deterioration at various sectors of the SPAs will further increase the density of nesting females, which, according to the density-dependent reduction in breeding success shown by our preliminary data (Martín 2008; own unpublished data), will eventually determine a significant decrease in the productivity of the population.

Acknowledgements We thank the 42 Group of the Spanish Air Forces for their generous cooperation in locating radio-tagged birds. The study was financed by the Dirección General de Investigación (projects PB97-1252, BOS2002-01543, and CGL2008-02567). We also thank the Consejería de Medio Ambiente, Comunidad de Madrid, for permits to capture and radio-tag the birds. Finally, we thank Luis M. Carrascal and José M. Álvarez for their help with statistical analyses, and the subject editor, Thomas W. P. Friedl, Christian A. Hagen and an anonymous reviewer for their useful comments on an earlier draft of the manuscript.

\section{References}

Alonso JC, Alonso JA (1990) Parámetros Demográficos, Selección de Hábitat y Distribución de la Avutarda en Tres Regiones Españolas. ICONA, Madrid 
Alonso JC, Magaña M, Palacín C, Martín C (2010) Correlates of male mating success in great bustard leks: the effects of age, weight and display effort. Behav Ecol Sociobiol 64:1589-1600

Alonso JC, Martin E, Alonso JA, Morales MB (1998) Proximate and ultimate causes of natal dispersal in the great bustard, Otis tarda. Behav Ecol 9:243-252

Alonso JC, Morales MB, Alonso JA (2000) Partial migration, and lek and nesting area fidelity in female great bustards. Condor 102:127-136

Alonso JC, Martín CA, Palacín C, Magaña M, Martín B (2003) Distribution, size and recent trends of the great bustard Otis tarda population in Madrid region, Spain. Ardeola 50:21-29

Alonso JC, Martín CA, Alonso JA, Palacín C, Magaña M, Lane SJ (2004) Distribution dynamics of a Great Bustard metapopulation throughout a decade: influence of conspecific attraction and recruitment. Biodivers Conserv 13:1659-1674

Alonso JC, Palacín C, Martín CA (2005) La Avutarda Común en la Península Ibérica: población actual y método de censo. SEO/BirdLife. Madrid

Andersson M, Wiklund CG (1978) Clumping versus spacing out: experiments on nest predation in fieldfares Turdus pilaris. Anim Beh 26: 1207-1212

Bergerud AT (1988) Increasing the numbers of grouse. In: Bergerud AT, Gratson MW (eds) Adaptive strategies and population ecology of northern grouse. University of Minnesota Press, Minneapolis, pp 686-731

Bergerud AT, Gratson MW (1988) Adaptive strategies and population ecology of northern grouse. University of Minnesota Press, Minneapolis

BirdLife International (2004) Birds in Europe. Population estimates, trends and conservation status. Bird/Life International, Cambridge

Bradbury JW, Gibson RM, Mccarthy CE, Vehrencamp SL (1989) Dispersion of displaying male Sage Grouse: II: The role of female dispersion. Behav Ecol Sociobiol 24:15-24 
Connelly JW, Schroeder MA, Sands AR, Braun CE (2000) Guidelines to manage Sage Grouse populations and their habitats. Wildl Soc Bull 28:967-985

Demeter L (1995) The spatial distribution of Great bustard Otis tarda nests in relation to solitary males in eastern Hungary. Áquila 102:53-60

Ena V, Martinez A, Thomas DH (1987) Breeding success of the Great bustard Otis tarda in Zamora Province, Spain, in 1984. Ibis 129:364-370

ESRI. (2005) Arc View GIS 9.2, Online users manual. Environmental Systems Research Institute, California.

Farago S, Giczi F, Wurm H (2001) Management for the Great Bustard Otis tarda in western Hungary. Game Wildl Sci 18:171-181

Glutz UN, Bauer KM, Bezzel E (1973) Handbuch der Vögel Mitteleuropas. Akademische Verlagsgesellschaft, Frankfurt

Heredia B, Rose L, Painter M (1996) Globally Threatened Birds in Europe. Action Plans. Council of Europe Publishing, Strasbourg

Hidalgo de Trucios SJ, Carranza J (1990) Ecología y Comportamiento de la Avutarda Otis tarda. Universidad de Extremadura, Cáceres

Hingrat Y, Jalme M St, Chalah T, Orhant N, Lacroix F (2008) Environmental and social constraints on breeding site selection. Does the exploded-lek and hotspot model apply to the houbara bustard Chlamydotis undulata undulata? J Avian Biol $39: 393-404$

Höglund J, Robertson JGM (1990) Spacing of leks in relation to female home ranges, habitat requirements and male attractiveness in the great snipe (Gallinago media). Behav Ecol Sociobiol 26:173-180

Höglund J, Alatalo RV (1995) Leks. Princeton University Press, New Jersey 
Holloran M J, Anderson S H (2005) Spatial distribution of Greater Sage-Grouse nests in relatively contiguous sagebrush habitats. Condor 107:742-752

del Hoyo J, Elliot A, Sargatal J (eds) (1996) Handbook of the Birds of the World Vol 3. Lynx Edicions, Barcelona

Johnsgard PA (1994) Arena Birds: Sexual Selection and Behavior. Smithsonian

Institution Press, Washington, DC

Kollar HP (1996) Action plan for the great bustard Otis tarda in Europe. In: Heredia B, Rose L, Painter M (eds) Globally threatened birds in Europe. Council of Europe, Strasbourg, pp 245-260

Lane SJ, Alonso JC, Martín CA (2001) Habitat preferences of great bustard Otis tarda flocks in the arable steppes of central Spain: are potentially suitable areas unoccupied? J Appl Ecol 38:193-203

Langgemach T, Bellebaum J (2005) Predation and the conservation of ground-breeding birds in Germany. Vogelwelt 126:259-298

Magaña M (2007) Comportamiento Reproductivo de la Avutarda Común. PhD thesis, Univ Complutense, Madrid

Magaña M, Alonso J C, Martín CA, Bautista LM, Martín B (2010) Nest-site selection by Great Bustards Otis tarda suggests a trade-off between concealment and visibility. Ibis 152:77-89

Manly BF (1997) Randomization, bootstrap and Monte Carlo methods in biology. Chapman 479 and Hall, London

Martín B (2008) Dinámica de población y viabilidad de la Avutarda Común en la Comunidad de Madrid. PhD thesis, Univ Complutense, Madrid 
Martín CA., Alonso JC, Alonso JA, Palacín C, Magaña M, Martín B. (2008). Natal dispersal in great bustards: the effect of sex, local population size and spatial isolation. J Anim Ecol 77:326-334

Martín CA, Alonso JC, Alonso JA, Palacín C, Magaña M, Martín B (2007) Sex-biased juvenile survival in a bird with extreme size dimorphism, the great bustard Otis tarda. J Avian Biol 38:335-346

Martínez C (1991a) Selección de micro-hábitat en una población de avutarda Otis tarda de un medio agrícola. Doñana Acta Vertebrata 18:173-185

Martínez C (1991b) Patterns of distribution and habitat selection of a Great Bustard Otis tarda population in northwestern Spain. Ardeola 38:137-147

Millspaugh JJ, Marzluff JM (2001) Radio Tracking and Animal Populations. Academic Press, San Diego

Morgado R, Moreira F (2000) Sasonal population dynamics, nest site selection, sex ratio and clutch size of the great bustard Otis tarda in two adjacent lekking areas. Ardeola 47:237-246

Osborne PE, Alonso JC, Bryant RG (2001) Modelling landscape-scale habitat use using GIS and remote sensing: a case study with great bustards. J Appl Ecol 38:458471

Pepper G W (1972) The ecology of sharp_tailed grouse during spring and summer in the aspen parklands of Saskatchewan. Saskatchewan Department of Natural Resources Wildlife Report 1

Schroeder MA, White GC (1993) Dispersion of greater prairie chicken nests in relation to lek location: evaluation of the hot-spot hypothesis of lek evolution. Behav Ecol 4: 266-270 
Suárez F, Naveso, MA, de Juana E (1997) Farming in the drylands of Spain: birds of the pseudosteppes. In: Pain DJ, Pienkowski MW (eds) Farming and Birds in Europe. The Common Agricultural Policy and its Implications for Bird Conservation. Academic Press, London

Sárez-Seoane S, Osborne P, Alonso JC (2002) Large-scale habitat selection by agricultural steppe birds in Spain: Identifying species-habitat responses using generalized additive models. J Appl Ecol 39: 755-771

StatSoft Inc (2001) STATISTICA (data analysis software system) V6.0, Tulsa

Streich WJ, Pitra C, Litzbarski H, Quaisser C (1996) Zur Populationsdynamik der Grosstrappe (Otis t. tarda L.) eine Computersimulation. Natursch Landschaftspfl Brandenb 5:91-94

Trail PW, Adams ES (1989) Active mate choice at cockof-the-rock leks: tactics of sampling and comparison. Behav Ecol Sociobiol 25:283-292

Viada C (1998) Áreas importantes para las aves en España. Iberdrola-SEO, Madrid Wakkinen WL, Reese KP, Connelly JW (1992) Sage Grouse nest locations in relation to leks. J Wildl Manage 56:38-383

Wegge P (1985) Spacing pattern and habitat use of capercaillie hens in spring. Proc Int Symp on Grouse 3:261-277

Wegge P, Rolstad J (1986) Size and spacing of capercaillie leks in relation to social behaviour and habitat. Behav Ecol Sociobiol 19:401-408 
Table 1 Lek sizes and mean lek- to-nest distances

\begin{tabular}{|c|c|c|c|c|c|}
\hline & \multicolumn{2}{|c|}{ Lek size } & \multicolumn{3}{|c|}{ Lek-to-nest distance } \\
\hline & $\partial^{\pi}$ & 우우 & Mean & SD & $\mathrm{n}$ \\
\hline Lek A & 68 & 219 & 8.42 & 6.76 & 23 \\
\hline Lek B & 14 & 50 & 3.08 & 3.37 & 5 \\
\hline Lek C & 24 & 73 & 8.36 & 9.90 & 13 \\
\hline Lek D & 29 & 94 & 5.12 & 5.26 & 10 \\
\hline
\end{tabular}


Table 2 Differences in hatching success (i.e. the percentage of nests where at least one egg hatched) between nests located inside and outside lek areas and the Special Protection Area

\begin{tabular}{|c|c|c|c|c|c|c|c|c|c|c|}
\hline & \multicolumn{5}{|c|}{ Lek areas } & \multicolumn{5}{|c|}{ Special Protection Area } \\
\hline & within & outside & $\chi^{2}$ & $P$ & $\mathrm{n}$ & within & outside & $\chi^{2}$ & $P$ & $\mathrm{n}$ \\
\hline $\begin{array}{l}\text { First-year } \\
\text { clutches }\end{array}$ & 47.4 & 67.6 & 2.10 & 0.148 & 53 & 60 & 61.5 & 0.01 & 0.921 & 53 \\
\hline $\begin{array}{l}\text { All year } \\
\text { clutches }\end{array}$ & 56 & 72.2 & 3.13 & 0.077 & 120 & 66 & 69.6 & 0.11 & 0.743 & 120 \\
\hline
\end{tabular}




\section{Legends for the Figures:}

Fig. 1 Map of the study area in central Spain, showing first-year nest-sites of the 55 marked females (black dots), lek areas defined for the four leks A-D where females were captured (black solid line polygons), and centres of the ten leks found in the study area (stars). The limits of the two Special Protection Areas (thin solid lines) and the border between Madrid and Guadalajara provinces (dashed line) are also shown. Shaded patches show the areas used by the birds through the year, and white areas in-between represent unsuitable habitat. Each nest is identified by a number identifying the female, followed by a letter corresponding to the lek where the female was observed during the mating season.. Female nesting in 6E (nesting area north of the SPAs) copulated in a lek centred $54 \mathrm{~km}$ south of that nest-site (outside the study area), and female nesting in $16 \mathrm{~F}$ (in the small SPA) mated in the lek centred $3 \mathrm{~km}$ southwest of her nest-site.

Fig. 2 Frequency distribution of the distances between the first-year nests of the 55 females radio-tracked and the centres of the leks where they were observed during the mating season. 


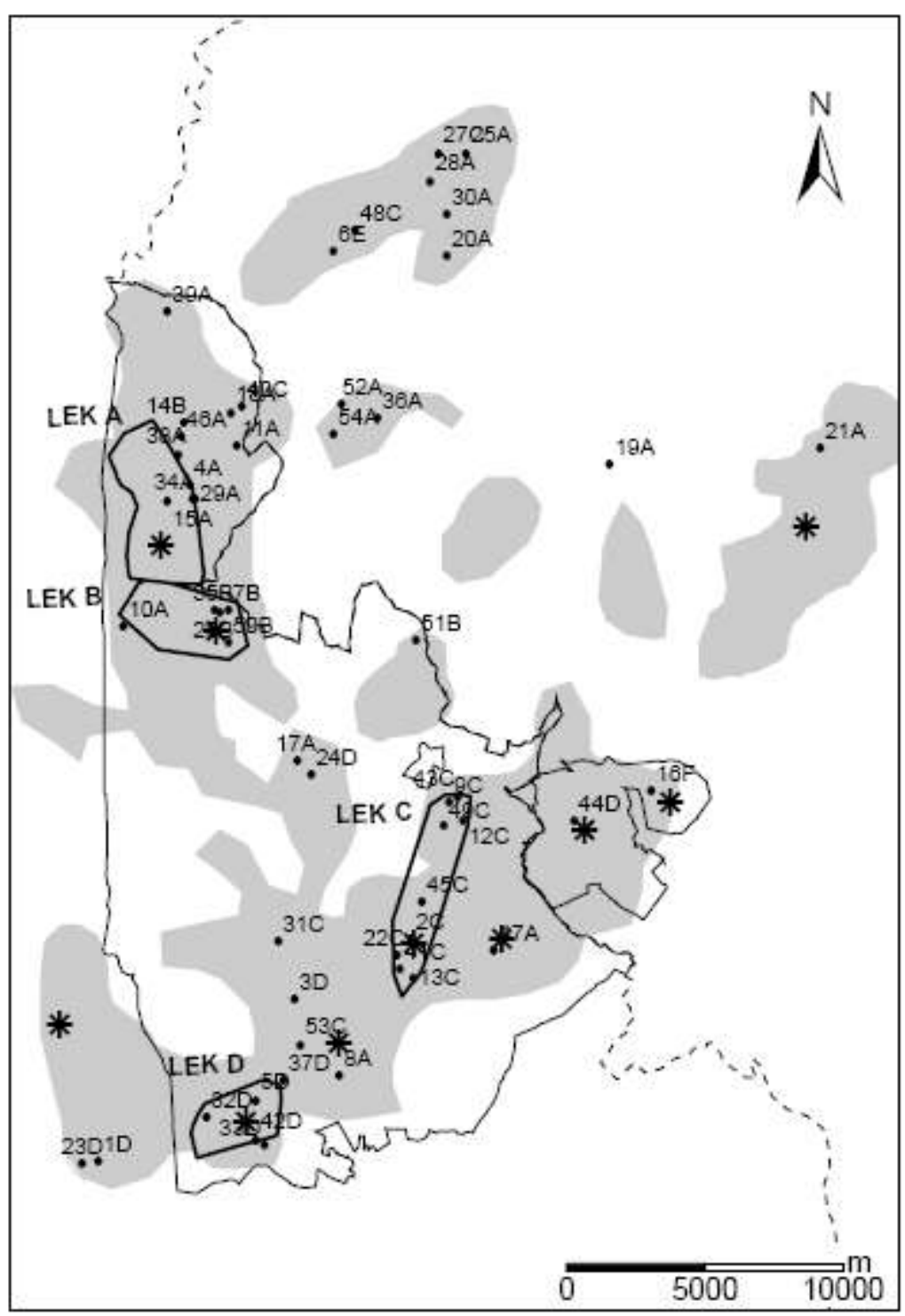

Figure 1 


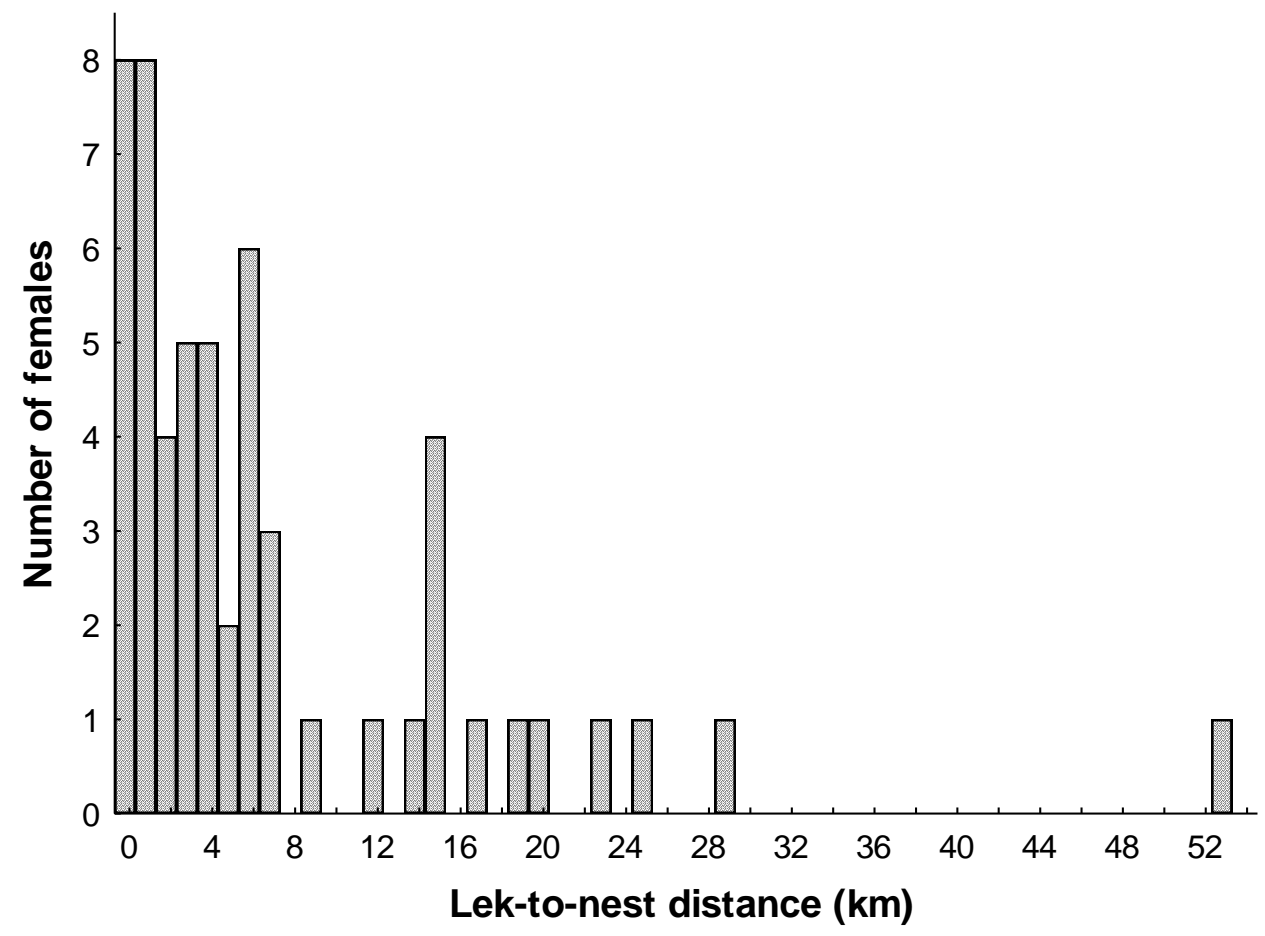

Figure 2 